\title{
Assessment of Pendimethalin, Quizalfop Ethyl and Imazethapyr on Weed Count of Cuscuta and Yield Attribute of Lentil
}

\author{
C.N. Choudhary and Nishant Prakash* \\ Krishi Vigyan Kendra, Arwal, Bihar, India \\ *Corresponding author
}

\section{A B S T R A C T}

\begin{tabular}{|l|}
\hline K e y w o r d s \\
$\begin{array}{l}\text { Cuscuta, Pendimethalin, } \\
\text { Imazethapyr, Quizalfop } \\
\text { ethyl, Weed count, Pod } \\
\text { number, Yield }\end{array}$ \\
\hline Article Info \\
\hline $\begin{array}{l}\text { Accepted: } \\
\text { 12 March } 2018 \\
\text { Available Online: } \\
10 \text { April } 2018\end{array}$ \\
\hline
\end{tabular}

\section{Keywords}

\section{Introduction}

Cuscuta campestris Yuncker (field dodder) belongs to the member of the Convolvulaceae family and is an annual obligate stem parasite. C. campestris is totally dependent on its host plants for assimilates, nutrients and water supply. In India, it is a serious problem in lentil, chickpea, linseed, greengram and blackgram especially in rice-fallows. Yield losses to the tune of $87 \%$ in lentil, $85.7 \%$ in chickpea and $49.7 \%$ in linseed have been reported due to severe infestation of field dodder (Moorthy et al., 2003). Manual removal and frequent inter row cultivation before the parasite attaches the host plant are the usual control measures. However, these methods are laborious and often not effective. Once the parasite is attached to the host it remains parasitic until harvest. In the prevailing widespread infestation and severe yield loss herbicides may be the best option for management of Cuscuta.

Several soil-applied herbicides are used for the management of Cuscuta. These herbicides are applied prior or immediately after the emergence of Cuscuta seedlings. It prevents the attachment of Cuscuta from the host and results in selective management of Cuscuta appropriately (Mishra 2009 Cudney et al., 1992; Dawson, 1990a; Orloff and Cudney, 1987). Effective control of Cuscuta with pendimethalin in different crops have been 
reported by several workers (Mahere et al., 2000 in linseed; Kumar, 2000 and Mishra et al., 2004 in blackgram; Dawson, 1990 and Orloff et al., 1989 in alfalfa; Rao and Rao, 1993 in onion). Pendimethalin $0.5-1.5 \mathrm{~kg} / \mathrm{ha}$ applied as pre emergence controlled Cuscuta in niger (Mishra et al., 2005), blackgram (Rao and Rao, 1993; Mishra et al., 2004), linseed (Mahere et al., 2000), onion (Rao and Rao, 1993), chickpea and lentil (Mishra et al., 2003). Liu et al., (1990) reported that pendimethalin inhibited the cell division and formation of spindle microtubules in the cells of germinated Cuscuta seedlings. Parker (1991) stated that post-attachment control of a parasite is very important in order to reduce its seed production and further spread, although irreversible damage is already done. Postemergence application of imazethapyr (50 and $100 \mathrm{~g} / \mathrm{ha})$ and glyphosate (50 g/ha) inhibited the growth of extended vines of Cuscuta and checked its growth upto 25-30 days only. It resulted in maximum seed yield of lentil (4175 and $3407 \mathrm{~kg} / \mathrm{ha}$ ), chickpea (3615 and 2949 $\mathrm{kg} / \mathrm{ha})$ and linseed (1994 kg/ha) as recorded in Cuscuta free plots (Mishra et al., 2005).

In black gram, imazethapyr at 50-100 g/ha and glyphosate at $1250 \mathrm{~g} / \mathrm{ha}$ significantly checked the Cuscuta infestation as compared to control. Maximum leaf area $\left(848 \mathrm{~cm}^{2}\right)$ and dry matter (4.03 g/plant) obtained from weed-free plot. Pendimethalin, fluchloralin, squadran (PE) and imazethapyr (50 g) application have been reported to cause significant increase in leaf area and plant dry weight as compared to Cuscuta-infested plots. Post-emergence application of pendimethalin (500 g), squadran $(1500 \mathrm{~g})$ and imazethapyr (100 g) was, however, phytotoxic to blackgram. In green gram, Imazethapyr $100 \mathrm{~g} / \mathrm{ha}$ at $15-20 \mathrm{DAS}$ inhibited all kind of weed and recorded less dry weight of weeds $(52.09 \mathrm{~g} / \mathrm{m} 2)$ and it was closely followed by quizalofop-p-ethyl 100 $\mathrm{g} / \mathrm{ha}$ at 15-20 DAS. Imazethapyr and Quizalofop-p-ethyl $100 \mathrm{~g} / \mathrm{ha}$ at 15-20 DAS also recorded higher per cent weed mortality (74.52 and $64.44 \%$, respectively) and weed control efficiency $(84.38$ and $83.76 \%$, respectively). Imazethapyr and Quizalofoppethyl $100 \mathrm{~g} / \mathrm{ha}$ at 15-20 DAS were found equally effective in grain increasing and straw yield over other treatments (Ali et al., 2011).

\section{Materials and Methods}

Field experiments were conducted during rabi seasons of 2014-15 and 2015-16 at the eight different farmers' field (N 2509', E084 $29^{\prime}$, $412 \mathrm{~m}$ above mean sea level) at Musepur village of Arwal district Bihar. The soil of experiment plots was clay loam (Typic Chromusterts), medium in available nitrogen (261 kg/ha), low in available phosphorus (11.44 $\mathrm{P} \mathrm{kg} / \mathrm{ha}$ ) and medium in potassium $(172.6 \mathrm{~kg} / \mathrm{ha})$, content having organic carbon $0.49 \%$ and $\mathrm{pH}$ value 7.04 . Treatments $(1,2$ and 3) were replicated eight times in a randomized block design and the crops were grown with recommended package of practices except weed control. Cuscuta seeds were treated with concentrated sulfuric acid for $20 \mathrm{~min}$ before broadcasting them in the field to break seed dormancy and to facilitate proper germination. Twenty Cuscuta seeds were sown along with the crop in rows $25 \mathrm{~cm}$ apart in $1 \mathrm{~m}^{2}$ micro-plots. All the weeds, except Cuscuta, were removed from the plots manually as and when required. Fluchloralin was incorporated in the soil before sowing. Pendimethalin (ready mixture of pendimethalin (30 EC @ 1.0 L a.i. /ha) were applied as pre-emergence herbicides (2days after sowing-DAS). Imazethapyr and glyphosate were applied as post-emergence (30 DAS) as blanket application. Herbicides were applied as a spray by knapsack sprayer fitted with flat fan nozzle at a spray volume of 500 litre per hectare. Population of Cuscuta was recorded seven days after application of pre-emergence herbicides and attachment of C. campestris to lentil plants was recorded at 
30, 60 and 90 DAS. Plant height was recorded at harvest. Crop yields and seed production of Cuscuta were determined by harvesting lentil, chickpea and linseed at maturity stage. Two central rows were harvested, threshed, cleaned and weighed. Cuscuta seeds were separated during cleaning and weighed separately. Seed number was estimated based on 1000-seed weight $(0.80 \mathrm{~g})$ and expressed on $\mathrm{m}^{-2}$ basis.

\section{Results and Discussion}

The result of herbicidal treatment of three herbicide namely Pendimethalin, Quizalfop ethyl and Imazethapyr on weed count of Cuscuta, average number of pods per plant and yield of lentil during the year of 2014-15 and 2015-16 are presented in Table1 and Table 2.

\section{Weed count}

In the year 2013-14, all the three treatments showed significant reduction of weed count over the control. Minimum number of Cuscuta weed count was recorded in treatment Pendimethalin $\left(\mathrm{T}_{1}\right)$ followed by Quizalphop ethyl $\left(\mathrm{T}_{3}\right)$, Imazethapyr $\left(\mathrm{T}_{2}\right)$ and control $\left(\mathrm{T}_{0}\right)$ where no herbicide was applied. Weed count in $\mathrm{T}_{1}, \mathrm{~T}_{2}, \mathrm{~T}_{3}$ and $\mathrm{T}_{0}$ were $21,88,82$ and 105 cuscuta per metre square respectively, at 40 days after sowing (DAS). Weed count in treatment $T_{1}$ is statistically significant in comparison to $\mathrm{T}_{0}, \mathrm{~T}_{2}$ and $\mathrm{T}_{3}$ i.e. treatment Pendimethalin caused the maximum weed reduction and performed better than Quizalfop ethyl, Imazethapyr and control. Treatment $\mathrm{T}_{2}$ and $\mathrm{T}_{3}$ were statistically significant in comparison to $\mathrm{T}_{0}$ while they were at par with each other i.e. both the Quizalfop ethyl and Imazethapyr performed better than control and they equally effective in reduction of weed. In the year 2015-16, again all the three treatments resulted in significant reduction in weed count over control. Again, minimum number of weed count was recorded in case of treatment $\mathrm{T}_{1}$ (24) followed by $\mathrm{T}_{3}(27), \mathrm{T}_{2}$ (32) and $T_{0}$ (43). $T_{1}$ was statistically significant in comparison to $\mathrm{T}_{2}$ and $\mathrm{T}_{0}$ while statistically at par with $\mathrm{T}_{3}$ i.e. Pendimethalin performed better than Quizalfop ethyl but its efficacy was the same as Imazethapyr. $\mathrm{T}_{2}$ was statistically significant in comparison to $\mathrm{T}_{0}$ and statistically at par with $\mathrm{T}_{3}$. However $\mathrm{T}_{3}$ was statistically at par with both the $T_{1}$ and $T_{2}$. In the year 2015-16, the performance of Imazethapyr was equivalent to Pendimethalin and Quizalfop ethyl in terms of weed count.

\section{Average no. of pods/plant of lentil}

In the year 2014-15, maximum number of pods per plant was recorded in $\mathrm{T}_{1}$ (64) followed by $\mathrm{T}_{3}$ (57), $\mathrm{T}_{2}$ (54) and $\mathrm{T}_{0}(51) . \mathrm{T}_{1}$ was statistically significant in comparison to $\mathrm{T}_{2}$ and $\mathrm{T}_{0}$ while statistically at par with $\mathrm{T}_{3}$. It implies that Pendimethalin results in better pod formation in comparison to Quizalfop ethyl and control, however, it is the same as Imazethapyr. Treatment $\mathrm{T}_{2}, \mathrm{~T}_{3}$ and $\mathrm{T}_{0}$ were statistically at par, which signifies that treatment Quizalfop ethyl and Imazethapyr did not result in better pod formation in comparison to control. In the year, 2015-16, $T_{1}$ and $T_{3}$ were statistically significant with $T_{2}$ and $T_{0}$ whereas $T_{1}$ and $T_{3}$ as well as $T_{2}$ and $T_{0}$ were statistically at par with each other. Pendimethalin and Imazethapyr were similar but better than control while Quizalfop ethyl is also similar to control in terms of their effect on no. of pod per plant.

\section{Yield}

The maximum yield obtained during 2014-15 was in $\mathrm{T}_{1}(13.7 \mathrm{q} / \mathrm{ha})$ followed by $\mathrm{T}_{3}(11.2$ $\mathrm{q} / \mathrm{ha}), \mathrm{T}_{2}(11.1 \mathrm{q} / \mathrm{ha})$ and $\mathrm{T}_{0}(10.5 \mathrm{q} / \mathrm{ha}) . \mathrm{T}_{1}$ was statistically significant from $T_{2}, T_{3}$ and $T_{0}$ i.e. Pendimethalin resulted best in comparison to Quizalfop ethyl, Imazethapyr and control. $\mathrm{T}_{3}$ was statistically significant from $\mathrm{T}_{0}$ but at par with $\mathrm{T}_{2}$. 
Table.1 Assessment of the performance of different pre and post emergence herbicides for control of parasitic weed (Cuscuta sp.) in lentil (Rabi 2014-15)

\begin{tabular}{|c|}
\hline Treatments \\
\hline $\begin{array}{l}\mathrm{T}_{1} \text { (Pendimethalin } 30 \mathrm{EC} \\
\text { @ } 1.0 \text { L a.i./ha) }\end{array}$ \\
\hline $\begin{array}{l}\mathrm{T}_{2} \text { (Quizalphop ethyl } 30 \\
\text { DAS @ 50g a.i./ha) } \\
\end{array}$ \\
\hline $\begin{array}{l}T_{3} \text { (Imazethapyr30 DAS } \\
\text { @ } 10 \% \text { SL 40g a.i/ha) } \\
\end{array}$ \\
\hline $\mathrm{T}_{0}$ (Control) \\
\hline SEM \pm \\
\hline CD 5\% \\
\hline $\mathbf{C V}$ \\
\hline
\end{tabular}

\begin{tabular}{|c|c|c|}
\hline $\begin{array}{c}\text { Weed Count (Cuscuta)/ } \\
\left.\mathbf{m}^{\mathbf{2}} \mathbf{( 4 0} \mathbf{D A S}\right)\end{array}$ & $\begin{array}{c}\text { Avg. No. of pods/plant of } \\
\text { lentil }\end{array}$ & $\begin{array}{c}\text { Lentil Yield } \\
(\mathbf{Q} . / \text { ha) }\end{array}$ \\
\hline $18^{\mathrm{c}}$ & $64^{\mathrm{a}}$ & $13.7^{\mathrm{a}}$ \\
\hline $88^{\mathrm{b}}$ & $54^{\mathrm{b}}$ & $11.1^{\mathrm{bc}}$ \\
\hline $82^{\mathrm{b}}$ & $57^{\mathrm{ab}}$ & $11.2^{\mathrm{b}}$ \\
\hline $105^{\mathrm{a}}$ & $51^{\mathrm{b}}$ & $10.5^{\mathrm{c}}$ \\
\hline 23.9 & 2.86 & 0.71 \\
\hline 15.20 & 7.95 & 0.669 \\
\hline 19.95 & 13.54 & 5.35 \\
\hline
\end{tabular}

\section{Table.2 Assessment of the performance of different pre and post emergence herbicides for} control of parasitic weed (Cuscuta sp.) in lentil (Rabi 2015-16)

\begin{tabular}{|c|c|c|c|}
\hline Treatments & $\begin{array}{c}\text { Weed Count (Cuscuta sp.)/ } \mathrm{m}^{2} \\
\text { (40 DAS) }\end{array}$ & $\begin{array}{l}\text { Avg. No. of pods/plant of } \\
\text { lentil }\end{array}$ & $\begin{array}{l}\text { Lentil Yield } \\
\text { (Q./ha) }\end{array}$ \\
\hline $\begin{array}{l}\mathrm{T}_{1} \text { (Pendimethalin } 30 \mathrm{EC} \\
\text { @ 1.0 L a.i./ha) }\end{array}$ & $24^{\mathrm{b}}$ & $63^{\mathrm{a}}$ & $13.5^{\mathrm{a}}$ \\
\hline $\begin{array}{l}T_{2} \text { (Quizalphop ethyl30 } \\
\text { DAS @ 50g a.i./ha) }\end{array}$ & $32^{\mathrm{bc}}$ & $53^{\mathrm{b}}$ & $11.7^{\mathrm{bc}}$ \\
\hline $\begin{array}{l}\mathrm{T}_{3} \text { (Imazethapyr30 DAS } \\
@ 10 \% \text { SL 40g a.i/ha) } \\
\end{array}$ & $27^{\mathrm{c}}$ & $60^{\mathrm{a}}$ & $12.6^{\mathrm{ab}}$ \\
\hline $\mathrm{T}_{0}$ (Control) & $43^{\mathrm{a}}$ & $48^{\mathrm{b}}$ & $11.1^{\mathrm{c}}$ \\
\hline SEM \pm & 4.6 & 2.8 & 0.49 \\
\hline CD 5\% & 5.6 & 6.79 & 1.05 \\
\hline $\mathrm{CV}$ & 17.34 & 11.66 & 8.26 \\
\hline
\end{tabular}

Fig.1 Assessment of the performance of different pre and post emergence herbicides for control of parasitic weed (Cuscuta sp.) in lentil (Rabi 2014-15)

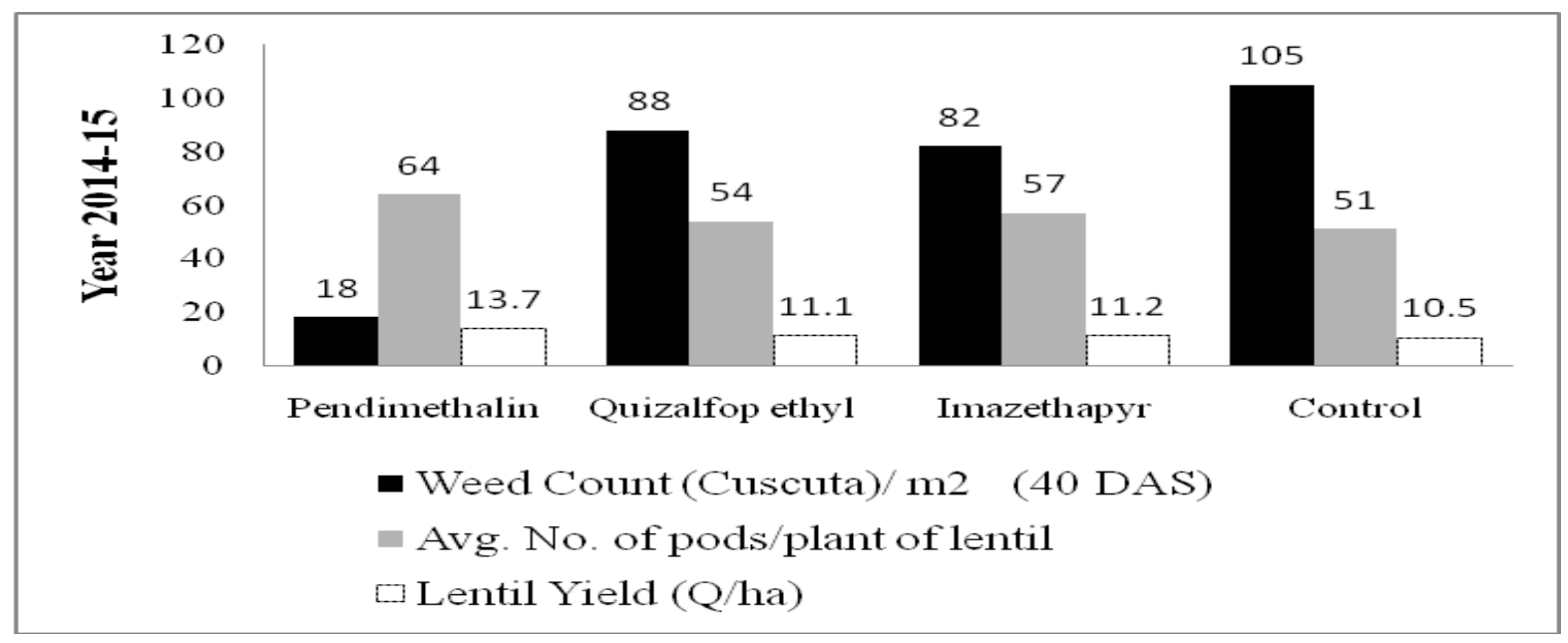


Fig.2 Assessment of the performance of different pre and post emergence herbicides for control of parasitic weed (Cuscuta sp.) in lentil (Rabi 2015-16)

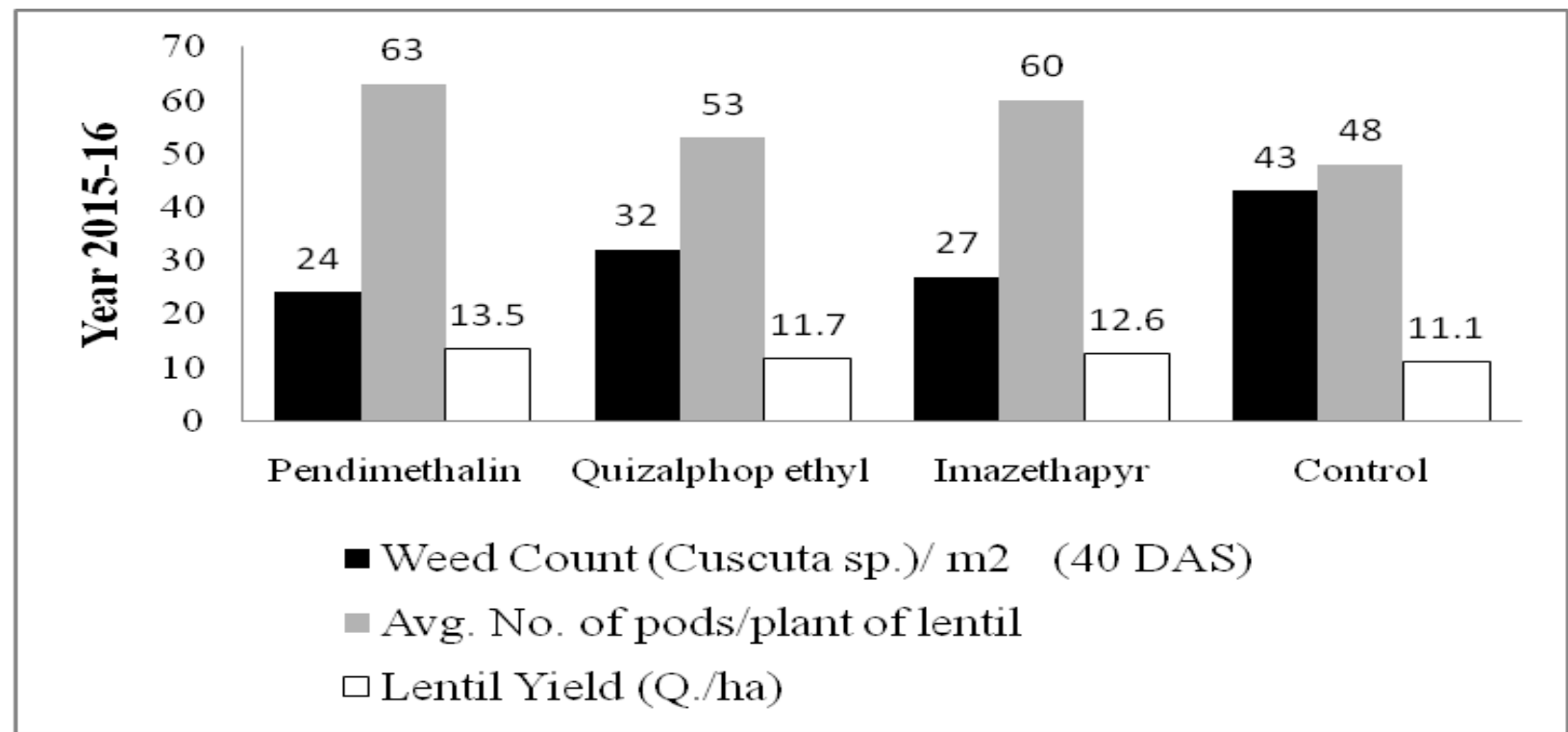

It implies that Imazethapyr was better than control, but its efficacy was the same as Quizalfop ethyl. $\mathrm{T}_{2}$ was statistically at par with $\mathrm{T}_{0}$ i.e. efficacy of the Quizalfop ethyl was the same as control where no herbicide was applied. During the year 2015-16, results were similar to 2014-15. During 2015-16, maximum yield $(13.5 \mathrm{q} / \mathrm{ha})$ was obtained in $\mathrm{T}_{1}$ followed by $\mathrm{T}_{3}(12.6 \mathrm{q} / \mathrm{ha}), \mathrm{T}_{2}(11.7 \mathrm{q} / \mathrm{ha})$ and $\mathrm{T}_{0}(11.1 \mathrm{q} / \mathrm{ha}) . \mathrm{T}_{1}$ was statistically significant from $\mathrm{T}_{2}$ and $\mathrm{T}_{0}$ but at par with $\mathrm{T}_{3} \cdot \mathrm{T}_{3}$ is statistically significant from $\mathrm{T}_{0}$ but at par with $\mathrm{T}_{2}$. During the year 2015-16 also the Pendimethalin performed the best as compared to other herbicide.

In both the years Pendimethalin, Quizalfopethyl and Imazethapyr caused significant reduction of Cuscuta weed density in lentil. Pendimethalin inhibited growth of both the narrow and broad leaf leaf weeds in lentil (Chaudhary et al., 2011). In lentil and chick pea, pendimethalin and Imazethapyr application resulted in significant reduction in weed density of Cuscuta (Mishra et al., 2005). In alfa-alfa, significant reduction of Dodder seedlings is achieved by post emergence application of Imazethapyr (Cudney and Lanini, 2000). Selective control of dodder was achieved by Pendimethalin in carrot, onion and alfalfa (Orloff and Cudney, 1987). In green gram, weed density was significantly influenced by Pendimethalin, Imazethapyr and Quizalfop ethyl however the lowest weed density was recorded in case of Pendimethalin but in case of Imazethapyr and Quizalfop ethyl treatments was the same (Ali et al., 2011). In niger also, pendimethalin results in significant reduction in Cuscuta density (Mishra et al., 2009). These results are in conformity with our findings.

In case of Black gram use of Pendimethalin and Imazethapyr enhanced the pod formation of in comparison to Cuscuta infected plots (Mishra et al., 2005). In lentil and chick pea, Pendimethalin at the rate of $1 \mathrm{~kg} / \mathrm{ha}$ increase seed yield significantly (Mishra et al., 2005). Paraxon, Whipsuper, Ronstar and Topstar are herbicidal treatments of lentil and applied after sowing of seed, significantly reduce weed population and increased number of pods per plant as compared to untreated plots (Akhtar et al., 2013). Significantly higher 
number of capsules per plant were harvested from herbicide butralin treatment, followed by metosulam, tribenuron-methyl, and fluazifop-p-butyl, respectively in dodder infected flax crop (Soliman and Hamza, 2010). All these findings are in congruency with our findings. In the present investigation, pods per plant increased by Pendimethalin, Imazethapyr and Quizalfop treatments.

Mishra et al., 2007 reported that dodder caused significant yield loss in Niger $(85.9 \%$ yield loss) followed by greengram $(81.6 \%)$ sesame $(66.8 \%)$, soybean $(48 \%)$, blackgram (27\%), pigeonpea $(24.8 \%)$ and groundnut $(17.8 \%)$. Pre-emergence application of Pendimethalin and post emergence application of imazethapyr reduces density of Cuscuta and increased yield significantly in chick pea, lentil and linseed whereas Imazethapyr did not result in significant yield increase, rather showed phytotoxic effect (Mishra et al., 2005). In black gram, preemergence application of Fluchloralin and Pendimethalin significantly increased yield (Kumar et al., 2000, Mishra et al., 2004), however post emergence application of glyphosate and bentazone did not control Cuscuta weed effectively and there was no significant increase in yield (Kumar et al., 2000). Lentil yield was significantly higher in Pendimethalin treated plots (Chaudhary et al., 2011). All these findings are in conformity with our findings. In present investigation, the maximum yield increase was recorded in Pendimethalin treatment whereas the yield increase by Imazethapyr and Quizalfop ethyl treatments were at par with control.

In this investigation, Pendimethalin caused maximum reduction of weed count in comparison to Imazethapyr and Quizalfop ethyl and control. Average number of pod per plant and yield was also recorded maximum in case of Pendimethalin as compared to Imazethapyr and Quizalfop ethyl and control.
Hence, Pendimethalin was found best in management of cuscuta.

\section{Acknowledgement}

I am extending my gratitude to Krishi Vigyan Kendra Arwal and Bihar Agriculture University, Sabour, Bhagalpur for providing all kind of support required for conducting this experiment.

\section{References}

Aktar S., Hossain M. A., Siddika A., Naher N. and Amin M. R. 2013. Efficacy of Herbicides on the Yield of Lentil (Lens culinaris Medik.). The Agriculturists 11(1): 89-94.

Ali S., Patel J.C., Desai L.J. and Singh J. 2011. Effect of herbicides on weeds and yield of rainy season greengram (Vigna radiata L. Wilczek). Legume Res., 34 (4): $300-303$.

Chaudhary S. U., Iqbal J., Hussain M. and Wajid A. 2011. Economical weed control in lentils crop. The Journal of Animal and Plant Sciences, 21(4): 734737.

Cudney D.W. and Lanini W.T. 2000. Dodder. In O.C. Maloy and T.D. Murray (eds.), Encyclopedia of Plant Pathology, Volume I (pp. 376-379.). New York, NY: John Wiley and Sons, Inc.

Mishra, J. S., B. T. S. Moorthy and Bhan M. 2005. Relative tolerance of kharif crops to dodder and its management in niger. In: Extended Summaries. National Biennial Conference, ISWS, PAU, Ludhiana, April 6-9. 213-214.

Mishra, J. S., Bhan M. and Moorthy B. T. S. 2003. Efficacy of herbicides against Cuscuta in winter pulses. In: Abstr. Nati. Symp. on Pulses for Crop Diversification and Natural Resource Manage. December 20-22. ISPRD, IIPR, Kanpur. pp. 190-191. 
Mishra, J. S., Bhan M., Moorthy B. T. S. and Yaduraju N. T. 2003. Effect of seeding depth on emergence of Cuscuta with linseed and summer blackgram. Ind. $J$. Weed Sci. 35: 281-282.

Mishra, J. S., Bhan M., Moorthy B. T. S. and Yaduraju N. T. 2004. Bio-efficacy of herbicides against Cuscuta in blackgram [Vigna mungo (L.) Hepper]. Ind. J. Weed Sci. 36: 278-279.

Mishra, J. S., Moorthy B. T. S., Bhan M. and Yaduraju N. T. 2007. Relative tolerance of rainy season crops to field dodder (Cuscuta campestris) and its management in niger (Guizotia abyssinica). Crop Protection; 26: 625629.

Orloff S B, and Cudney DW (1987). Control of dodder in alfalfa with dinitroaniline herbicides. Proceedings of the Western Society of Weed Science, 40, 98-103.

Parker, C. 1991. Protection of crops against parasitic weeds. Crop Prot. 10:6-22.

Soliman I. E. and Hamza A. M. 2010. Evaluation of some herbicides against flax dodder (Cuscuta epilinum weihe) in fibre flax (linum ustatissimum 1.) Cultivation. Journal of Plant Protection Research 50 (3).

\section{How to cite this article:}

Choudhary, C.N. and Nishant Prakash. 2018. Assessment of Pendimethalin, Quizalfop Ethyl and Imazethapyr on Weed Count of Cuscuta and Yield Attribute of Lentil. Int.J.Curr.Microbiol.App.Sci. 7(04): 1386-1392. doi: https://doi.org/10.20546/ijcmas.2018.704.155 